\section{$\underset{\substack{\text { hommes } \\ \text { \& migrations }}}{ }$}

\section{Hommes \& migrations}

Revue française de référence sur les dynamiques

migratoires

1289 | 2011

Les frontières du sport

\title{
Le dernier été de la Boyita
}

Film argentin de Julia Solomonoff

\section{André Videau}

\section{Q OpenEdition \\ 1 Journals}

\section{Édition électronique}

URL : http://journals.openedition.org/hommesmigrations/821

DOI : 10.4000/hommesmigrations.821

ISSN : 2262-3353

\section{Éditeur}

Musée national de l'histoire de l'immigration

\section{Édition imprimée}

Date de publication : 1 janvier 2011

Pagination : 147

ISSN : 1142-852X

\section{Référence électronique}

André Videau, «Le dernier été de la Boyita », Hommes \& migrations [En ligne], 1289 | 2011, mis en ligne le 29 mai 2013, consulté le 22 septembre 2020. URL : http://journals.openedition.org/

hommesmigrations/821; DOI : https://doi.org/10.4000/hommesmigrations.821

Ce document a été généré automatiquement le 22 septembre 2020.

Tous droits réservés 


\title{
Le dernier été de la Boyita
}

\author{
Film argentin de Julia Solomonoff
}

\section{André Videau}

1 C'est le deuxième long-métrage, après Hermanas (2005), de Julia Solomonoff, personnalité omniprésente et polyvalente du jeune cinéma argentin. Outre la réalisation de téléfilms et de documentaires, elle est passée par la production et par des étapes fructueuses de l'assistanat, notamment auprès de Walter Salles pour Carnets de voyage (2003). Elle s'est aussi essayée avec succès au métier de comédienne, sa prestation dans Historias minimas (2002) de Carlos Sorin a été récompensée du prix Condor.

2 L'éclosion d'une sensibilité juvénile, et surtout féminine, a fait sensation dans de nombreux festivals (Cannes, Toulouse, Sofia, Miami...) et fourni des preuves éclatantes de la diversité des cinémas d'Amérique latine (Argentine, mais aussi Pérou, Bolivie, Brésil...) et de leur faculté à s'emparer de sujets hypersensibles encore enfouis sous les interdits d'ordres sociaux, familiaux, moraux, politiques ou religieux.

Les vacances de Jorgelina (Guadalupe Alonso) dans la propriété familiale, quelque part dans la pampa, auront le goût doux-amer de la fin d'une époque et du début d'un monde. Les troubles de la puberté, avec son cortège d'attirances et de rejets, d'angoisses profondes et de plaisirs à fleur de peau, vont venir bouleverser le flux régulier des jours, leur écoulement apparemment immuable au rythme ralenti de l'adolescence. Elle n'a plus guère d'affinités avec sa sœur aînée Sylvia (Sylvia Tavcar), soudain trop grande, trop adulte, qui l'exclut de l'intimité de leur chambre, de secrets sans partage, de cachotteries, de flux menstruels... Après avoir rongé son frein, elle va déporter son intérêt sur le fragile et joli Mario (Nicolas Treise), insolite fils des fermiers, sauvageon au regard séraphique. En réalité dissimulant sous ses airs farouches une "anomalie" qui trouble son identité sexuelle et provoque l'émoi de l'entourage, les railleries, les persécutions. 